\title{
KINERJA KOMISI PEMILIHAN UMUM DAERAH DALAM PROSES PEMILIHAN UMUM LEGISLATIF KABUPATEN SERAM BAGIAN TIMUR PROVINSI MALUKU TAHUN 2019
}

\author{
Oleh \\ Ali Rahman Rumaloak ${ }^{\mathbf{1}}$, \\ Sampara Lukman ${ }^{2}$, Etin Indrayani ${ }^{3}$ \\ 1) Pemerintah Daerah Kabupaten Seram Bagian Timur \\ Program Magister Terapan Studi Pemerintahan Daerah Institut Pemerintahan Dalam Negeri \\ alyrahman811@gmail.com \\ ${ }^{2,3)}$ Institut Pemerintahan Dalam Negeri
}

\begin{abstract}
"PERFORMANCE OF THE REGIONAL ELECTION COMMISSION IN THE LEGILATIVE ELECTION PROCESS OF SERAM REGENCY, EAST PART OF MALUKU PROVINCE IN 2019”
\end{abstract}

$T$ is research is motivated because of the writer's interest in researching the problems that arise regarding the Performance of the General Election Commission of the Legislative General Election of the East Seram Regency of the Province. Maluku. The author found the problem that the Regional General Election Commission of East Seram Regency is still weak in managing organizational performance in holding the East Seram Regency Legislative General Election, Maluku Province in 2019, this can be seen from the low level of community participation. Th is study aims to describe the performance of the Legislative General Election Commission of East Seram Regency, the supporting and inhibiting factors that influence it and the possible strategies to overcome obstacles in the legislative election process of East Seram Regency. The research method used a descriptive qualitative approach. By using Dwiyanto's theory.

Based on the research results, the performance of the Regional General Election Commissi in the Legislative Election Process of East Seram Regency is seen from the indicators of Productivity, Service Quality, Responsiveness, Responsibility, and Accountability which are still not optimal. This can be seen from the lack of budget and the difficulty of sea crossing facilities and infrastructure. Suggestions to the Regional General Election Commission in the Legislative Election Poses of East Seram Regency include: it is necessary to have good budget management, increase socialization, communicate and collaborate with other related agencies.

Keywords: performance, General Election Commission, regional head election

\section{AbSTRAK}

$\mathrm{P}$ enelitian ini dilatarbelakangi karena ketertarikan penulis meneliti terhadap permasalahan yang timbul mengenai Kinerja Komisi Pemilihan Umum Pemilihan Umum Legislatif Kabupaten Seram Bagian Timur Provinsi Maluku. Penulis menemukan masalah Komisi Pemilihan Umum Daerah Kabupaten Seram Bagian Timur masih lemah memanajemen kinerja organisasi dalam penyelenggaraan Pemilihan Umum Legislatif Kabupaten Seram Bagian Timur 
Provinsi Maluku Tahun 2019 hal tersebut terlihat dari tingkat partisipasi masyarakat yang masih rendah. Penelitian ini bertujuan untuk mendeskripsikan Kinerja Komisi Pemilihan Umum Legislatif Kabupaten Seram Bagian Timur, faktor-faktor pendukung dan penghambat yang memengaruhinya serta Strategi yang mungkin dilakukan untuk mengatasi hambatan dalam proses pemilihan Legislatif Kabupaten Seram Bagian Timur . Metode penelitian menggunakan pendekatan kualitatif deskriptif. Dengan menggunakan teori Dwiyanto.

Berdasarkan hasil penelitian bahwa kinerja Komisi Pemilihan Umum Daerah dalam Proses Pemilihan Umum Legislatif Kabupaten Seram Bagian Timur dilihat dari indikator produktivitas, kualitas layanan, responsivitas, responsibilitas, dan akuntabilitas masih kurang maksimal. Hal ini dapat dilihat dari minimnya anggaran serta sulitnya sarana dan prasarana penyeberangan laut. Saran kepada Komisi Pemilihan Umum Daerah dalam Poses Pemilihan Umum Legislatif Kabupaten Seram Bagian Timur antara lain: perlu pengelolaan anggaran yang baik, meningkatkan sosialisasi, melakukan komunikasi dan kerja sama dengan instansi lain yang terkait.

Kata kunci: kinerja, Komisi Pemilihan Umum, pemilihan legislatif

\section{PENDAHULUAN}

$\mathrm{P}$ emilihan umum menjadi salah satu indikator stabil dan dinamisnya demokratisasisuatubangsa. DiIndonesia, penyelenggaraan pemilu memang secara periodik sudah berlangsung sejak awal kemerdekaan bangsa ini, akan tetapi proses demokratisasi lewat pemilupemilu yang terdahulu belum mampu menghasilkan nilai-nilai demokrasi yang matang akibat sistem politik yang otoriter. Harapan untuk menemukan format demokrasi yang ideal mulai nampak setelah penyelenggaraan yang berjalan relatif cukup lancar dan aman. Untuk ukuran bangsa yang baru beberapa tahun lepas dari sistem otoritarian, penyelenggaraan pemilu yang terdiri dari pemilu legislatif dan pemilu kepala daerah secara langsung yang berjalan tanpa tindakan kekerasan menjadi prestasi bersejarah bagi bangsa ini.

Pemilihan umum yang selanjutnya disebut pemilu adalah sarana kedaulatan rakyat untuk memilih anggota Dewan Perwakilan Rakyat, Anggota Dewan Perwakilan Daerah, Kepala Daerah dan Wakil Kepala Daerah, dan untuk memilih anggota Dewan Perwakilan Rakyat Daerah, yang dilaksanakan secara langsung, umum, bebas, rahasia, jujur, dan adil dalam negara kesatuan republik indonesia berdasarkan pancasila dan Undang-Undang Dasar 1945.

Dalam Undang-Undang No. No. 7 Tahun 2017 tentang Penyelenggaraan Pemilihan Umum disebutkan Penyelenggara Pemilu adalah lembaga yang menyelenggarakan Pemilu yang terdiri atas Komisi Pemilihan Umum, Badan Pengawas Pemilu, dan Dewan Kehormatan Penyelenggaraan Pemilu sebagai satu kesatuan fungsi penyelenggaraan Pemilu untuk memilih anggota Dewan Perwakilan Rakyat, anggota Dewan perwakilan Daerah, Kepala daerah dan Wakil Kepala daerah, dan untuk memilih anggota Dewan Perwakilan Rakyat Daerah secara langsung oleh rakyat.

\section{Pemerintahan}

Bevir (2007: 138) dalam Wasistiono dan Simangunsong (2015: 87) menyebutkan bahwa "The term government comes from the Greek word "kuberman". Which means steering a ship". Selanjutnya Bevir membagi pengertian pemerintahan ke dalam dua pengertian, yaitu pemerintahan dalam arti sempit sebagai sebuah institusi (government as an institution), sedangkan dalam arti luas 
pemerintahan diartikan sebagai sebuah proses (government as a process).

Masih menurut pendapat Bevir, menjelaskan Pemerintahan dalam arti sempit merujuk pada wujud kewenangan negara dan diarahkan pada sekelompok orang yang memiliki kewenangan pada unit tertentu pada saat tertentu. Sedangkan pemerintahan dalam arti luas, pemerintah adalah cara untuk memerintah entitas tertentu pada saat tertentu pula. Kata pemerintah merujuk pada metode tertentu, tujuan, dan tingkatan pengendalian masyarakat oleh negara.

Ramlan Surbakti (1992) mengemukakan bahwa pemerintahan dapat ditinjau dari tiga aspek, yaitu segi kegiatan (dinamika), struktur fungsional dan segi tugas dan kewenangan (fungsi) dengan penjelasan:

"apabila ditinjau dari segi dinamika, pemerintahan berarti segala kegiatan atau usaha yang teroganisasikan, bersumber pada kedaulatan dan berlandaskan pada dasar negara, mengenai rakyat dan wilayah negara itu demi tercapainya tujuan negara (Surbakti , 1992: 163).

Masih menurut pendapat Ramlan Surbakti, mengemukakan bahwa:

"ditinjau dari segi fungsional, pemerintahan berarti seperangkat fungsi negara, yang satu sama lain berhubungan secara fungsional, dan melaksanakan fungsinya atas dasardasar tertentu demi tercapainya tujuan negara. Lalu ditinjau dari aspek kewenangan negara maka pemerintahan berarti seluruh tugas dan kewenangan negara (Surbakti, 1992: 163).

\section{Demokrasi}

Demokrasi merupakan suatu prinsip dasar tata kehidupan bermasyarakat, baik dalam interaksi sesama komponen masyarakat maupun antara masyarakat dengan pemerintahan/negara. Dalam rangka mewujudkan masyarakat sipil atau masyarakat madani, demokrasi adalah prasyarat mutlak. Sejak lengsernya pemerintahan orde baru pada 1998, demokrasi menjadi kosakata umum bagi siapa saja untuk menyatakan pendapat. Dari kalangan cendekiawan hingga kalangan awam. Secara Etimologis "demokrasi" terdiri dari dua kata yang berasal dari bahasa yunani, yaitu demos yang berarti rakyat atau penduduk suatu tempat, dan cratein atau cratos yang berarti kekuasaan atau kedaulatan, jadi kata demokrasi memiliki arti suatu sistem pemerintahan dari, oleh, dan untuk rakyat.

\section{Kinerja Organisasi}

Kinerja merupakan hasil kerja secara kualitas dan kuantitas yang dapat dicapai oleh seorang pegawai dalam melaksanakan tugas sesuai dengan tanggung jawab yang diberikan kepadanya. Definisi kinerja menurut Bambang Kusriyanto dalam A.A. Anwar Prabu Mangkunegara (2005: 9) mengatakan dalam bukunya bahwa, "Hampir semua kalangan seringkali menggunakan istilah kinerja, mulai dari media masa, pejabat birokrat, pelaku bisnis. Bahkan sampai masyarakat awam, namun demikian tidak ditemukan definisi yang definitif tentang kinerja."

\section{METODE PENELITIAN}

Penelitian ini adalah survei deskriptif, yaitu menggambarkan kenyataan yang ditemui di lapangan secara apa adanya. Penggunaan tipe ini bertujuan mengukur secara cermat dengan menggunakan metode kualitatif melalui penggambaran sistematis dan menghimpun fakta-fakta yang ada pada penelitian ini. Survei dibatasi pada penelitian yang datanya dikumpulkan dari informan yang mewakili.

Pendekatan yang digunakan dalam penelitian, yaitu metode kualitatif yang dikemukakan oleh Sugiyono (2005: 4) 
bahwa metode kualitatif adalah suatu metode penelitian yang digunakan untuk meneliti pada kondisi objek yang dialami (sebagai lawannya adalah eksperimen), di mana peneliti adalah instrument kunci.

Penentuan narasumber dilakukan secara purposive, yaitu dengan cara memilih orang-orang tertentu didasarkan pada pertimbangan informasi yang diperlukan dan memiliki pengetahuan tentang Kinerja Komisi Pemilihan Umum daerah dalam proses pemilihan Legislatif di Kabupaten Seram Bagian Timur.

\section{HASIL PENELITIAN DAN PEMBAHASAN}

\section{Kinerja Komisi Pemilihan Umum Daerah dalam Proses Pemilihan Umum Legislatif}

Dwiyanto(2008:50-51) mengungkapkan bahwa konsep produktivitas tidak hanya mengukur tingkat efisiensi, tetapi juga efektivitas pelayanan. Produktivitas pada Umumnya dipahami sebagai rasio antara input dengan output.

Kinerja Komisi Pemilihan Umum Daerah yang dimaksud adalah hasil kerja yang dicapai oleh Komisi Pemilihan Umum Daerah pada saat proses Pemilihan Legislatif di Kabupaten Seram Bagian Timur Provinsi Maluku Tahun 2019.

\section{- Produktivitas}

Produktivitas Komisi Pemilihan Umum Daerah Kabupaten Seram Bagian Timur dalam proses Pemilihan Legislatif di Kabupaten Seram Bagian Timur Provinsi Maluku sangat diperlukan, karena dapat menentukan persiapan awal yang dimiliki Komisi Pemilihan Umum Daerah Kabupaten Seram Bagian Timur sebagai penyelenggara proses Pemilihan Calon Legislatif di Kabupaten Seram Bagian Timur untuk melaksanakan pentas awal Daerah Kabupaten Seram Bagian Timur harus dilakukan dengan sangat cermat, sehingga dapat meminimalkan terjadinya kekurangan-kekurangan yang terjadi pada saat proses pemilihan legislatif.

\section{- Responsivitas}

Dwiyanto (2008: 50-51) responsivitas adalah kemampuan organisasi untuk mengenali kebutuhan masyarakat menyusun agenda dan prioritas pelayanan dan mengembangkan program-program pelayanan publik sesuai dengan kebutuhan dan aspirasi masyarakat. Responsivitas dimasukkan sebagai salah satu indikator kinerja organisasi publik dalam menjalankan misi dan tujuannya, terutama dalam memenuhi kebutuhan masyarakat.

Responsivitas sangat diperlukan dalam pelayanan publik karena hal tersebut merupakan bukti kemampuan organisasi untuk mengenali kebutuhan masyarakat, menyusun agenda dan prioritas pelayanan serta mengembangkan program-program pelayanan publik sesuai dengan kebutuhan dan aspirasi masyarakat

\section{- Responsibilitas}

Dwiyanto (2008: 50-51) responsibilitas menjelaskan apakah pelaksanaan kegiatan organisasi publik itu dilakukan sesuai dengan prinsip-prinsip administrasi yang benar atau sesuai dengan kebijakan organisasi, baikyang eksplisit maupun implisit. Kemampuan suatu organisasi dalam melaksanakan program kerja yang peka akan sasaran dan target, serta mengembangkan program-program pelayanan sesuai dengan kebutuhan dan aspirasi masyarakat merupakan tanggung jawab yang harus dimiliki Komisi Pemilihan Umum Daerah Kabupaten Seram Bagian Timur dalam proses Pemilihan Legislatif di Kabupaten Seram Bagian Timur.

Pelaksanaan kegiatan organisasi publik dengan prinsip-prinsip administrasi yang benar atau dengan kebijakan organisasi, baik yang eksplisit maupun implisit. Responsibilitas berkaitan dengan 
kedisiplinan kerja yang telah sesuai dengan peraturan pemerintah.

\section{- Akuntabilitas}

Dwiyanto (2008: 50-51) akuntabilitas publik menunjukkan pada seberapa besar kebijakan dan kegiatan organisasi publik tunduk pada para pejabat politik yang dipilih oleh rakyat, asumsinya adalah bahwa para pejabat politik tersebut karena dipilih oleh rakyatnya, dengan sendirinya akan selalu mempresentasikan kepentingan rakyat. Tingkat dari serangkaian tahapann proses Pemilihan Calon legislatif Kabupaten Seram Bagian Timur pada Umumnya telah sesuai dengan ketentuan yang telah ditetapkan oleh Komisi Pemilihan Umum Daerah yang mengacu kepada peraturan-peraturan yang digunakan pada saat proses pemilihan Legislatif untuk menuju pelayanan yang adil dan merata maka diperlukan suatu pencapaian hasil yang sudah dilaksanakan dari seluruh rangkaian programprogram yang telah terencana dan terlaksana dengan baik

\section{Faktor Pendukung dan Faktor Peng- hambat Kinerja Komisi Pemilihan Umum Daerah dalam Proses Pemilih- an Umum Legislatif}

Setiap adanya suatu kinerja, pasti ada kendala dan masalah yang menjadi faktor pendukung kinerja komisi Pemilihan Umum Daerah dalam Proses Pemilihan Umum Legislatif di Kabupaten Seram Bagian Timur Provinsi Maluku Tahun 2019.

\section{- Faktor Pendukung}

- Adanya peraturan yang mengatur Tugas dan Wewenang Komisi Pemilihan Umum Daerah.

Sebuah pelaksanaan program tentunya harus memiliki dasar hukum yang sah yang akan memberikan kewenangan pelaksananya dalam menjalankan berbagai rencana kegiatan yang telah disusun, sama halnya untuk kinerja
KPUD Kab. Seram Bagian Timur sehingga bisa leluasa dalam menjalankan tugasnya sehari-hari. Berkaitan dengan hal tersebut di atas penulis melakukan wawancara kepada Kisman Kilian selaku Ketua KPUD Kabupaten Seram Bagian Timur pada 12 Juni 2020 pukul 10,30 WIT di ruang kerjanya

\section{- Faktor Penghambat}

Setiap suatu kinerja, pasti ada kendala dan masalahyangmenjadi faktor penghambat untuk kesuksesan sebuah kinerja tersebut. Terkait penelitian ini, peneliti menganalisis faktor penghambat kinerja Komisi Pemilihan Umum Daerah Kabupaten Seram Bagian Timur

- Minimnya anggaran Komisi Pemilihan Umum Daerah Kabupaten Seram Bagian Timur sehingga Komisi Pemilihan Umum Daerah sulit melaksanakan tugas secara maksimal.

Strategi yang Dilakukan dalam Meningkatkan Kinerja Komisi Pemilihan Umum Daerah dalam Proses Pemilihan Umum Legislatif

Faktor internal yang memengaruhi kinerja komisi pemilihan umum dalam pemilihan Legislatif Kabupaten Seram Bagian Timur dapat dilihat pada kekuatan (strengths) dan kelemahan (weakness).

\section{- Kekuatan (Strengths)}

Berdasarkan hasil analisis dan pembahasan dari penelitian yang telah dilakukan, ditemukan beberapa faktor yang menjadi kekuatan (strengths) kinerja Komisi Pemilihan Umum Daerah dalam Pemilihan Legislatif Kabupaten Seram Bagian Timur antara lain sebagai berikut.

a. Adanya peraturan yang mengatur Tugas dan Wewenang Komisi Pemilihan Umum Daerah.

b. Tersedianya sumber daya KPU dari TPS, PPS, PPK, Komisioner KPU. 
c. Tersedianya aplikasi sistem aplikasi penghitungan suara

\section{- Kelemahan (Weakness)}

Berdasarkan analisis pembahasan dari hasil penelitian, kelemahan (Weakness) yang terdapat pada kinerja Komisi Pemilihan Umum Daerah dalam Pemilihan Legislatif Kabupaten Kabupaten Seram Bagian Timur adalah sebagai berikut.

a. Minimnya anggaran Komisi Pemilihan Umum Daerah Kabupaten Seram

Bagian Timur sehingga Komisi Pemilihan Umum Daerah sulit melaksanakan tugas secara maksimal

b. Kekurangan sumber daya staf pelaksana KPUD

c. Sulitnya berkoordinasi dengan PPK, PPS dan TPS di kecamatan di daerah kepulauan

Faktor eksternal pelaksanaan pemilihan legislatif oleh Komisi Pemilihan Umum Daerah Kabupaten Seram Bagian Timur dapat dilihat pada peluang (opportunities) dan ancaman (threats).

\section{- Peluang (Opportunities)}

Berdasarkan hasil analisis dam pembahasan dari penelitian yang telah dilakukan peluang, (opportunities)yang terdapat pada kinerja Komisi Pemilihan Umur Daerah dalam Pemilihan Legislatif Kabupaten Seram Bagian Timur Provinsi Maluku 2019 antara lain sebagai berikut.

a. adanya pelatihan untuk TPS, PPS, PPK dan staf KPUD

b. Adanya peran dan dukungan dari instansi-instansi dan aparat keamanan terkait yang ikut serta membantu Komisi Pemilihan Umum Daerah

c. Tersedianya sistem informasi pemungutan dan penghitungan suara (Situng) d. Adanya sarana dan prasarana yang disediakan untuk Komisi Pemilihan Umum Daerah dalam melakukan sosialisasi

e. Adanya aplikasi sistem pencalonan (Silon)

f. Adanya aplikasi sistem informasi data pilih (Sidali)

\section{- Ancaman (Threats)}

Berdasarkan analisis pembahasan dari hasil penelitian, ditemukan beberapa faktor yang menjadi ancaman (threats) kinerja komisi pemilihan umum daerah dalam Pemilihan Umum Legislatif Kabupaten Seram Bagian Timur Provinsi Maluku antara

\section{Strategi yang dilakukan dalam meningkatkan Kinerja Komisi Pemilihan Umum Daerah dalam Proses Pemilihan Umum Legislatif}

Teknik yang digunakan peneliti dalam menganalisis dan menyusun strategi dalam pembahasan subbab ini adalah dengan menggunakan teknis analisis SWOT. Analisis SWOT digunakan sabagai alat untuk menganalisis permasalahan yang terdapat dalam rumusan masalah yang berhubungan dengan faktor-faktor yang memengaruhi, yaitu faktor internal dan faktor eksternal dalam menyusun strategi yang digunakan untuk keberhasilan kinerja Komisi Pemilihan Umum Daerah dalam Pemilihan Legislatif Kabupaten Kabupaten Seram Bagian Timur Provinsi Maluku, yang kemudian peneliti tentukan isu-isu strategis menggunakan litmus test.

a. Memaksimalkan penggunaan aplikasi sistem informasi pemungutan dan penghitungan suara (Situng), aplikasi sistem pencalonan (Silon) d an aplikasi sistem informasi data pilih (Sidali)

b. Memaksimalkan koordinasi penyusunan perencanaan anggaran sesuai kebutuhan KPUD bersama pemerintah daerah 
c. Meningkatkan fasilitas distribusi logistik pemilu salah satunya penyewaan helikopter

d. Meningkatkan penegakan peraturanpengawasan dan saksi tegas terhadap calon legislatif yang melakukan politik uang

\section{SIMPULAN}

Berdasarkan hasil penelitian dan pembahasan Kinerja Komisi Pemilihan Umum Daerah dalam Proses Pemilihan Umum Legislatif Kabupaten Seram Bagian Timur Provinsi Maluku 2019 peneliti menyimpulkan berikut ini.

Pertama, kinerja Komisi Pemilihan Umum Daerah dalam proses Pemilihan Umum Legislatif Kabupaten Seram Bagian Timur dilihat dari:

a. Produktivitas Komisi Pemilihan Umum Daerah Kabupaten Seram Bagian Timur dalam proses Pemilihan Umum Umum Legislatif Kabupaten Seram Bagian Timur dapat dikatakan kurang maksimal. Hal ini dapat dilihat dari minimnya anggaran dan pencapaian target yang belum sesuai dengan program yang telah ditetapkan sebelumnya. Selain itu juga kendala lain seperti sulitnya infrastruktur penyeberangan laut di Kabupaten Seram Bagian Timur sehingga kurang maksimalnya produktivitas pada saat proses Pemilihan Umum Legislatif Kabupaten Seram Bagian Timur.

b. Kualitas layanan komisi pemilihan umum daerah proses Pemilihan Umum Legislatif Kabupaten Seram Bagian Timur sudah cukup berkualitas. Hal ini dilihat dari Pemberian Informasi yang dilakukan komisi pemilihan umum Kabupaten Seram Bagian Timur di media massa seperti surat kabar,Radio dan lainnya.

c. Responsivitas Komisi Pemilihan Umum Daerah Kabupaten Seram Bagian Timur dalam proses Pemilihan Umum Legislatif Kabupaten Seram Bagian Timur sudah cukup maksimal. Hal ini dapat terlihat dari daya tangkap kinerja Komisi Pemilihan Umum Daerah Kabupaten Seram Bagian Timur yang langsung memproses jika ada pengaduan dari masyarakat jika ada namanya yang tidak masuk dalam DPT Kemudian sesuai dengan keinginan masyarakat yang menginginkan pemilihan yang aman, lancar, bersih jujur dan adil.

d. Responsibilitas Komisi Pemilihan Umum Daerah Kabupaten Seram Bagian Timur dalam Proses Pemilihan Umum Umum Legislatif Kabupaten Seram Bagian Timur sudah cukup maksimal. Hal ini dapat dilihat dari tanggung jawab yang sudah terlaksana. Kemudian kerja sama Komisi Pemilihan Umum Daerah dengan instansi-instansi lain yang berjalan dengan baik.

e. Akuntabilitas Komisi Pemilihan Umum Daerah Kabupaten Seram Bagian Timur dalam Proses Pemilihan Umum Legislatif Kabupaten Seram Bagian Timur sudah cukup maksimal. Hal ini dapat dilihat tingkat kesesuaian data pemilih yang tidak ada terjadi masalah. Kemudian juga tindakan cepat yang Komisi Pemilihan Umum Daerah lakukan dalam mengatasi permasalahan yang terjadi.

Berdasarkan simpulan pengukuran kinerja Komisi Pemilihan Umum Daerah dalam proses pemilihan umum legislatif di Kabupaten Seram Bagian Timur maka secara umum dapat dikatakan kinerja komisi pemilihan umum sudah cukup baik dan maksimal karena empat dari lima indikator yang digunakan menunjukkan hasil yang baik yang menyatakan kualitas layanan yang cukup berkualitas, responsivitas yang cukup maksimal, rensponsibilitas yang cukup 
maksimal, serta akuntabilitas yang cukup maksimal. Catatan kurangnya kinerja hanya berada pada tingkat produktivitas yang disebabkan oleh persoalan anggaran serta kondisi alam yang diukur dengan indikator yang dikemukakan oleh Dwiyanto yang terdiri dari lima indikator.

Kedua, faktor pendukung Kinerja Komisi Pemilihan Umum Daerah dalam Proses Pemilihan Umum Legislatif Kabupaten Seram Bagian Timur Provinsi Maluku adalah:

1) Adanya peran dari instansi-instansi terkait yang ikut serta membantu komisi pemilihan umum daerah.

2) Adanya partisipasi dari tokoh masyarakat.

3) Adanya sarana dan prasarana yang memadai di Komisi Pemilihan Umum Daerah Kabupaten Seram Bagian Timur.

Ketiga, faktor penghambat Kinerja Komisi Pemilihan Umum Daerah dalam Proses Pemilihan Umum Legislatif Kabupaten Seram Bagian Timur Provinsi Maluku adalah:

1) Ketersediaan anggaran yang minim

2) Tingkat kesadaran masyarakat akan pentingnya menggunakan hak suara untuk memilih kepala daerah masih rendah.

3) Sulitnya infrastruktur penyeberangan laut yang dihadapi komisi pemilihan daerah Kabupaten Seram Bagian Timur untuk menyalurkan logistik pemilihan ke tiap-tiap Kecamatan.

Keempat, strategi yang dilakukan dalam meningkatkan Kinerja Komisi Pemilihan Umum Daerah dalam Proses Pemilihan Umum di Kabupaten Seram Bagian Timur adalah:

1) Memaksimalkan penggunaan aplikasi sistem informasi pemungutan dan penghitungan suara (Situng), aplikasi sistem pencalonan (Silon) dan aplikasi sistem informasi data pilih (Sidali).
2) Memaksimalkan koordinasi penyusunan perencanaan anggaran sesuai kebutuhan KPUD Bersama pemerintah daerah.

3) Meningkatkan fasilitas distribusi logistik pemilu salah satunya penyewaan helikopter.

4) Meningkatkan penegakan peraturanpengawasan dan saksi tegas terhadap calon legislatif yang melakukan politik uang.

\section{SARAN}

Berdasarkan hasil penelitian dan pembahasan serta simpulan di atas terkait Kinerja komisi pemilihan Umum Daerah dalam proses Pemilihan Umum Legislatif Kabupaten Seram Bagian Timur Provinsi Maluku Tahun 2019 penulis memberikan saran sebagai berikut.

1. Hendaknya Kinerja Komisi Pemilihan Umum Daerah dalam Proses Pemilihan Umum Legislatif Kabupaten Seram Bagian Timur Provinsi Maluku Perlu ditingkatkan lagi meliputi aspek Produktivitas, kualitas layanan, responsivitas, responsibilitas dan akuntabilitas.

2. Adanya faktor penghambat Kinerja Komisi Pemilihan Umum Daerah dalam Proses Pemilihan Umum Legislatif Kabupaten Seram Bagian Timur Provinsi Maluku tahun 2019, maka hendaknya KPU Seram Bagian Timur perlu mengatasi kendala-kendala tersebut dengan memanfaatkan peluang yang ada, agar terciptanya keberhasilan yang maksimal pada pemilihan yang akan datang.

3. Strategi yang dilakukan terkait Kinerja komisi pemilihan Umum Daerah dalam proses pemilihan umum Umum Legislatif Kabupaten Seram Bagian Timur Provinsi Maluku, yaitu dengan:

a. Perlu ditingkatkan lagi Sosialisasi yang dilakukan kepada masyarakat 
agar masyarakat sadar akan pentingnya memilih legislatif.

b. Komisi Pemilihan Umum Daerah dalam Proses Pemilihan Umum Umum Legislatif Kabupaten Seram Bagian Timur perlu lebih banyak lagi melakukan komunikasi dan kerja sama dengan instansi lainnya sebagai referensi komisi pemilihan umum daerah dalam menerima masukan-masukan dan melaksanakan tanggung jawab.

\section{DAFTAR RUJUKAN}

A.A Anwar Prabu Mangkunegara. 2005. Manajemen Sumber Daya Manusia Perusahaan. Bandung: PT remaja Rosdakarya

Adisasmita, Raharjo. 2011. Manajemen Pemerintah Daerah. Graha Ilmu, Yogyakarta.

Amirudin, dan Bisri A. Zaini., 2006. Pilkada Langsung Problem dan Prospek. Yogyakarta: Pustaka Pelajar.

Arikunto, S. 2010. Prosedur Penelitian Suatu Pendekatan Praktik. Jakarta: Rineka Cipta.

Bryson, John, M. 2011. Perencanaan Strategis Bagi organisasi Sosial. Jakarta: Pustaka Pelajar

Budiarjo, Miriam. 1994. Partisipasi dan Partai Politik (sebuah bunga rampai). Jakarta: Yayasan Obor Indonesia.

Bawaslu. 2009. Pedoman Pengawasan Pemilu 2009. Jakarta: Election-MDP.

Cameron, Kim S., Robert E. Quinn. 1999. Diagnosing and Changing Organizational Culture: Based on the Competing Values Framework. Reading, Masachusetts: Addison Wesley

Creswell, John, W., 2016, Resrarch Design, Pustaka Pelajar, Yogyakarta.

Dwiyanto, Agus, 2008. Reformasi Birokrasi Publik di Indonesia. Yogyakarta: Gajah Mada University Press
Fahmi, Irham, 2015, Manajemen Kinerja Teori dan Aplikasi, Alfabeta, Bandung

Hatten, K. J. and hatten, M. L. 1996. "Strategi Groups, Asymmetrical Mobility Barriers, and Contesbility", Strategi Management Journal. United States of america: elsevier Inc

Hubeis, Musa dan Mukhamad Najib. 2014. Manajemen Strategis dalam Pengembangan Daya Saing Organisasi. Gramedia. Jakarta

Inu Kencana Syafiie. 2009. Pengantar Ilmu Pemerintahan. Cetakan Kelima. Bandung: Refika Aditama

Keban, T. Yeremias. 2004. Enam Dimensi Strategis Administrasi Publik, Konsep, Teori dan Isu. Gava media. Yogyakarta

KPU. 2010. Modul: Pemilihan Umum. Jakarta: Komisi Pemilihan Umum.

Mahfud, Moh. MD. 2003. Demokrasi dan Konstitusi di Indonesia, Jakarta: Rhineka Cipta.

Mahsun, Mohamad, 2006. Pengukuran Kinerja Sektor Publik. Yogyakarta: BPFE

Mas'oed, Mohtar dan MacAndrews. 2001. Perbandingan Sistem Politik. Yogyakarta: Gajah Mada University Press.

Marrus. 2002. Manajemen Pelayanaan Umum di Indonesia. PT Bumi Aksa. Jakarta

Moleong, Lexy J. 2013. Metode Penelitian Kualitatif. Edisi Revisi. Bandung: PT Remaja Rosdakarya.

Nazir. 1988. Metode Penelitian. Jakarta: Ghalia Indonesia.

Ndraha, Taliziduhu. 2011. Kybernologi Sebuah Rekonstruksi Ilmu Pemerintahan. Jakarta: Rineka Cipta

Paslong, Harbani, 2013,Metode Penelitian Administrasi Publik, Alfabeta, Bandung

Pahmi Sy. 2010. Politik Pencitraan. Jakarta: Gaung Persada Press

Prawirosentono, Suryadi. 1999. Kebijakan Kinerja Karyawan. Yogyakarta: BPFE.

Pradhanawati, Ari., 2005. Pilkada Langsung Tradisi Baru Demokrasi Lokal. Surakarta: KOMPIP. 
Prihatmoko, Joko J., 2005. Pemilihan Kepala Daerah Langsung: Filosofi, Sistem dan Problema Penerapan di Indonesia. Yogyakarta: Pustaka Pelajar.

Purwanto. 2010. Metode Penelitian Kuantitatif. Bandung: Remaja Rosda Karya.

Rangkuti Freddy. 2014. Analisis SWOT: Teknik Membedah Kasus Bisnis. Jakarta: PT Gramedia Pustaka Utama

Rush, Michael dan Althoff, Philips. 2003. Pengantar Sosiologi Politik. Jakarta: Raja Grafindo Persada.

Said, Gatara, A.A dan Dzulkiah, Said, Moh., 2007. Sosiologi Politik: Konsep dan Dinamika Perkembangan Kajian. Jakarta: Pustaka Setia.

Simangungsong, Fernandes, 2016, Metodologi Penelitian Pemerintahan, Alfabeta, Bandung

Sugiyono. 2005. Metode Penelitian Bisnis. Bandung: Alfabeta

Sugiyono, 2013, Metode Penelitian Kuantitatif, Kualitatif dan $R \& D$, Alfabeta, Bandung

Suharsaputra, Uhar, 2012, Metode Penelitian,Kuantitatif, Kualitatif dan $R$ \& $D$, Alfabeta, Bandung

Suradji, 2009, Pengembangan Kinerja Pelayanan Publik, Refika Aditama, Jakarta.

Sudarmanto. 2009. Kinerja dan Pengembangan Kompetensi SDM. Yogyakarta: Pustaka Pelajar

Suhartono. 2009. "Tingkat kesadaran Politik Pemilih Pemula dalam Pilkada; suatu Refleksi School-Based democracy Education (Studi Kasus Pilkada Provinsi Banten Jawa Barat)". Hasil Penelitian. Pascasarjana UPI.

Surbakti, Ramlan, 2009. Memahami Ilmu Politik. Jakarta: Gramedia Widya Pustaka
Suyadi Prawirosentono. 1999. Manajemen Sumber Daya Manusia (Kebijakan Kinerja Karyawan), Kiat Membangun Organisasi Kompetitif Menjelang Perdagangan Bebas Dunia, Edisi Pertama. Yogyakarta: BPFE

Syafhendry. 2016. Perilaku Pemilih "Teori dan Praktik". Pekanbaru: Alaf Riau

Syafiie, Inu Kencana. 2009. Pengantar Ilmu Pemerintahan. Refika Aditama. Bandung

Steers, R.M. and Porter, L. W. 2003. Motivation and Work Behavior. New York: Mc GrawHill Book Company

Thoha, Miftah. 1995. Pembinaan Organisasi (Proses Diagnosis dan Intervensi). Jakarta: Raja Grafindo Persada.

Ubaidillah, A. dan Abdul Rozak. 2000. Pendidikan Kewarganegaraan (Civic education): Demokrasi, Hak Asasi Manusia dan Masyarakat Madani. IAIN Jakarta Press, Jakarta

Wasistiono, Sadu dan Simangungsung, Fernandes, 2015 Metodologi Ilmu Pemerintahan (Edisi Revisi yang Diperluas), IPDN Press, Jatinangor

Winardi, J, 2004, Manajemen Perilaku Organisasi, Prenada Media, Jakarta

\section{Peraturan Perundang-Undangan}

Undang-Undang Dasar Republik Indonesia Tahun 1945

Undang-Undang No. 15 Tahun 2011 tentang Penyelenggaraan Pemilihan Umum

UU No. 8 Tahun 2012 tentang Pemilihan Umum Anggota Dewan Perwakilan Rakyat, Dewan Perwakilan Daerah, dan Dewan Perwakilan Daerah

Undang-Undang No. No. 7 Tahun 2017 tentang Penyelenggaraan Pemilihan Umum 